\title{
Autoradiographic localization of inhibitory and excitatory amino acid neurotransmitter receptors in human normal and olivopontocerebellar atrophy cerebellar cortex
}

\author{
Roger L. Albin and Sid Gilman \\ Department of Neurology, University of Michigan, Ann Arbor, MI 48104 (U.S.A.)
}

(Accepted 26 December 1989)

Key words: Cerebellar cortex; $\gamma$-Aminobutyric acid; Glutamate; $N$-Methyl-D-aspartate; Quisqualate; Benzodiazepine; Granule cell; Purkinje cell; Olivopontocerebellar atrophy

\begin{abstract}
We used standard techniques of receptor autoradiography to study the distribution of inhibitory and excitatory amino acid neurotransmitter receptors in human normal cerebellar cortex. Benzodiazepine (BDZ) receptor density was relatively high in both granule cell and molecular layers. $\mathrm{GABA}_{\mathrm{A}}$ receptor density was highest in granule cell layer with lower receptor density in molecular layer. There was a lower density of $\mathrm{GABA}_{\mathrm{B}}$ receptors than $\mathrm{GABA}_{\mathrm{A}}$ receptors in both molecular and granule cell layers with a relatively higher density of $\mathrm{GABA}_{\mathrm{B}}$ receptors in molecular layer than in granule cell layer. In granule cell layer, the density of the $N$-methyl-D-aspartate (NMDA) subtype of excitatory amino acid receptors was greatest whereas in molecular layer the quisqualate $(\mathrm{QA})$ receptor subtype density was greatest. With [ $\left.{ }^{3} \mathrm{H}\right] N$ (1-[2-thienyl]cyclohexyl)3-4-piperidine as a ligand, there was no specific binding to the phencyclidine receptor. Molecular layer was also characterized by relatively high density of a non-NMDA/non-QA displaceable glutamate binding site. We studied also the cerebellar cortex of 4 cases of olivopontocerebellar atrophy (OPCA), a syndrome in which Purkinje and granule cells degenerate. In these specimens, there was significant decrement of $B D Z$ and $\mathrm{GABA}_{\mathrm{A}}$ receptors in both molecular and granule cell layers, with loss of $\mathrm{GABA}_{\mathrm{B}}$ receptors in molecular layer. NMDA receptors were depleted in granule cell layer while QA receptors and the non-NMDA/non-QA glutamate binding site were significantly depleted in molecular layer. Our normal human and OPCA data are largely consistent with animal data about the cellular localization of cerebellar cortical amino acid neurotransmitter receptors.
\end{abstract}

\section{INTRODUCTION}

The relatively simple architecture and uniform organization of the cerebellar cortex have made it a favored area for the study of synaptic physiology and neurotransmitter action ${ }^{21}$. Excitatory amino acids and gamma aminobutyric acid (GABA), the primary excitatory and inhibitory neurotransmitters of the central nervous system, are thought currently to mediate most synaptic events within the cerebellar cortex. The excitatory amino acid glutamate (GLU) is probably the neurotransmitter of mossy fibers while the closely related excitatory amino acid aspartate may be the neurotransmitter of climbing fibers $^{3,16,17,41,47,50,57}$. Granule cells appear to use GLU as their neurotransmitter ${ }^{21,43,49,61}$ while Purkinje cells, stellate cells, basket cells, and Golgi cells are thought to be GABAergic ${ }^{22,28,36,59}$.

Both excitatory amino acid and GABA receptors possess subtypes. Two general types of GABA receptor are recognized. $\mathrm{GABA}_{\mathrm{A}}$ receptors mediate inhibition through a chloride ion channel modulated by the linked benzodiazepine $(\mathrm{BDZ})$ receptor ${ }^{14}$. $\mathrm{GABA}_{\mathrm{B}}$ receptors modulate potassium or calcium channels through second messenger systems ${ }^{6}$. Excitatory amino acid receptors have been divided into 3 categories, $N$-methyl-Daspartate (NMDA), quisqualate (QA), and kainate receptors, based on studies of these relatively selective agonists $^{33}$. Associated with the NMDA receptor ionophore is the phencyclidine (PCP) receptor, the binding site for PCP and other dissociative anesthetics ${ }^{33}$. Receptor binding techniques, particularly receptor autoradiography (ARG), have been used to define the anatomic distribution of excitatory amino acid and GABA receptors within the cerebellar cortex of experimental animals ${ }^{7,12,18,34,35,37-39,42,62}$. Application of receptor binding techniques to animals with genetic, toxin, or viral induced degeneration of specific cerebellar cortical neuron subpopulations and afferents has given valuable information about the cellular localization of different neurotransmitter receptors within cerebellar cortex ${ }^{2,8-}$ $11,23,27,31,32,34,35,42,45,46,48,58$.

In this report, we describe the distribution of $\mathrm{GABA}_{\mathrm{A}}$, $\mathrm{GABA}_{\mathrm{B}}, \mathrm{BDZ}, \mathrm{NMDA}, \mathrm{QA}$, and PCP receptors in normal human cerebellar cortex as determined by ARG.

Correspondence: R.L. Albin, Neuroscience Laboratory Building, 1103 E. Huron, Ann Arbor, MI 48104, U.S.A. 
In addition, we studied the distribution of these receptors in cerebellar cortical specimens from individuals suffering from olivopontocerebellar atrophy (OPCA), a clinically and genetically heterogeneous syndrome in which degeneration of cerebellar cortical neurons, particularly Purkinje and granule cells, and loss of climbing fiber and mossy fiber afferents are constant features ${ }^{4,19}$. The use of OPCA specimens is comparable to the use of rodents with genetic, viral, or toxin induced loss of cerebellar cortical neuron subpopulations and afferents and permits inferences about the cellular localization of these receptors. A preliminary account of this work has appeared ${ }^{1}$.

\section{MATERIALS AND METHODS}

\section{Materials}

$\left[{ }^{3} \mathrm{H}\right] \mathrm{GABA},\left[{ }^{3} \mathrm{H}\right]$ flunitrazepam, and $\left[{ }^{3} \mathrm{H}\right] \mathrm{GLU}$ were purchased from Amersham (Arlington Heights, IL). $\left[{ }^{3} \mathrm{H}\right] \mathrm{N}-(1-[2$-thienyl]cyclohexyl)3-4-piperidine (TCP) was purchased from NEN-Dupont (Boston, MA). Non-radioactive NMDA and QA were purchased from Cambridge Research Biochemicals (Valley Stream, NY). Non-radioactive PCP was a generous gift from Dr. James $H$. Woods. Tritium sensitive film was purchased from LKB (Ultrofilm; Piscataway, NJ). The remaining reagents were purchased from various commercial suppliers and were of the highest possible purity.

\section{Human specimens}

Blocks of cerebellar cortex were obtained at autopsy from 12 individuals and then stored at $-70^{\circ} \mathrm{C}$. We studied 4 cases of pathologically verified OPCA. One case was sporadic, and the remaining 3 were from pedigrees with autosomal dominant inheritance. Two of the latter cases were from a well studied pedigree ${ }^{44}$. The mean age at death was 38 years (range 15 to 72 ). The mean postmortem delay from autopsy to freezing was $3.25 \mathrm{~h}$ (see Tsiotos et al. for a more extensive description of these $\operatorname{cases}^{52}$ ). For controls, we used 4 specimens from individuals without neurologic disease, and 4 from individuals with neurologic disease not affecting the cerebellar cortex. There was one case of multiple sclerosis, one of Friedreich's ataxia, one of Huntington's disease, and one of Alzheimer's disease. The mean age at death was 54 years (range 23 to 87 ), and the mean postmortem delay was $13.7 \mathrm{~h}$. Specimens from individuals with neurologic disease not affecting the cerebellar cortex were included to control for the effects of chronic neurologic disease and motor disability.

\section{Autoradiography}

Tissue blocks were warmed overnight to $-20{ }^{\circ} \mathrm{C}$ and sectioned at $20 \mu \mathrm{m}$ on a Lipshaw cryostat. Sections were thaw-mounted onto gelatin-coated slides. Slides were stored at $-20^{\circ} \mathrm{C}$ until the time of assay. For GLU receptors, all experiments were performed within $48 \mathrm{~h}$ of sectioning. All GABA receptor assays were done within 72 $h$ of sectioning, and BDZ and PCP receptors were assayed within 5 days of sectioning. All ARG assays followed the same basic procedure. Slides were prewashed in incubation buffer at $4{ }^{\circ} \mathrm{C}$, air-dried under a stream of cool air, and then immersed in incubation buffer at $4{ }^{\circ} \mathrm{C}$ with tritiated ligand and appropriate blocking agents. Following incubation with ligand solutions the slides were rinsed and dried under a stream of hot air. Slides were apposed to tritium sensitive film along with known radioactive standards and stored for varying lengths of time in light tight cassettes. Films were developed in Kodak D-19 and analyzed using the MCID image processing system (Imaging Research, St. Catherines, Ontario). Film density was converted into bound radioactivity with a polynomial regression curve derived from the standards. All slides were run in duplicate and at least 50 readings were taken of each area. Molecular and granule cell layers were readily identified in all specimens, but the Purkinje cell layer was not consistently identifiable. Measurements of receptor density were confined consequently to granule cell and molecular layers. Receptor density was assessed at a single concentration of tritiated ligand in each assay. All receptor assays have been described previously and used for analysis of human postmortem tissue $e^{13,29,54,60}$.

For assay of BDZ receptors, slides were prewashed in $50 \mathrm{mM}$ Tris-citrate buffer ( $\mathrm{pH} \mathrm{7.0)}$ for $30 \mathrm{~min}$, then incubated for $30 \mathrm{~min}$ in the same buffer containing $5 \mathrm{nM}\left[{ }^{3} \mathrm{H}\right]$ flunitrazepam (specific activity $=85 \mathrm{Ci} / \mathrm{mmol}$ ). Slides then received one quick dip in buffer, followed by two 5 -min washes. Non-specific binding was assessed by addition of $2 \mu \mathrm{M}$ clonazepam.

For assay of PCP receptors, slides were prewashed in $50 \mathrm{mM}$ Tris-acetate buffer ( $\mathrm{pH} \mathrm{7.4)}$ for $30 \mathrm{~min}$, then incubated for $45 \mathrm{~min}$ in the same buffer plus $1 \mathrm{mM} \mathrm{Mg}$-acetate containing $20 \mathrm{nM}\left[{ }^{3} \mathrm{H}\right] \mathrm{TCP}$ (specific activity $=60 \mathrm{Ci} / \mathrm{mmol}$ ). Slides then received three 1 -min washes in Tris-acetate plus $\mathrm{Mg}$-acetate buffer. Non-specific binding was assessed by addition of $20 \mu \mathrm{M}$ PCP.

GABA receptors were assayed with $20 \mathrm{nM}\left[{ }^{3} \mathrm{H}\right] \mathrm{GABA}$ (specific activity $=105 \mathrm{Ci} / \mathrm{mmol}$ ). Slides were prewashed for $30 \mathrm{~min}$ in 50 $\mathrm{mM}$ Tris- $\mathrm{HCl}$ plus $2.5 \mathrm{mM} \mathrm{CaCl}_{2}$ ( $\mathrm{pH} 7.4$ ), then incubated in the same buffer containing radioactive ligand. $\mathrm{GABA}_{\mathrm{A}}$ receptors were selectively assayed by adding $100 \mu \mathrm{M}$ baclofen, and $\mathrm{GABA}_{\mathrm{B}}$ receptors by addition of $10 \mu \mathrm{M}$ isoguvacine. Non-specific binding was assessed by addition of both $100 \mu \mathrm{M}$ baclofen and $100 \mu \mathrm{M}$ isoguvacine. After incubation in the ligand solution, slides were rinsed with 3 rapid squirts of buffer followed by one squirt of $2.5 \%$ glutaraldehyde in acetone.

NMDA and QA receptors were assayed with $20 \mathrm{nM}\left[{ }^{3} \mathrm{H}\right] \mathrm{GLU}$ (specific activity $=48-53 \mathrm{Ci} / \mathrm{mmol}$ ). QA receptor density was determined by subtracting from total $\left[{ }^{3} \mathrm{H}\right] \mathrm{GLU}$ binding the amount displaced by $2.5 \mu \mathrm{M}$ QA when $\left[{ }^{3} \mathrm{H}\right] \mathrm{GLU}$ binding was examined in $50 \mathrm{mM}$ Tris- $\mathrm{HCl}$ plus $2.5 \mathrm{mM} \mathrm{CaCl} 2$ buffer (pH 7.2). NMDA receptor density was assayed in $50 \mathrm{mM}$ Tris-acetate buffer ( $\mathrm{pH} 7.2)$ plus $2.5 \mu \mathrm{M}$ QA. For NMDA binding, non-specific binding was assessed by addition of $1 \mathrm{mM}$ GLU. In previous studies of rat and postmortem human brain we found these two assays to be the best

\section{TABLE I}

Neurotransmitter receptor density in control human and olivopontocerebellar cerebellar cortex (OPCA)

All values in $\mathrm{fmol} / \mathrm{mg}$ prot. (mean \pm S.E.M.).

\begin{tabular}{|c|c|c|c|}
\hline Receptors & Control & $O P C A$ & \% Change \\
\hline \multicolumn{4}{|l|}{ Benzodiazepine } \\
\hline Granule cell layer & $482 \pm 28$ & $163 \pm 27$ & $-65^{*}$ \\
\hline Molecular layer & $521 \pm 42$ & $319 \pm 5$ & $-39^{* *}$ \\
\hline \multicolumn{4}{|l|}{$\mathrm{GABA}_{\mathrm{A}}$} \\
\hline Granule cell layer & $1195 \pm 47$ & $804 \pm 91$ & $-37^{*}$ \\
\hline Molecular layer & $365 \pm 28$ & $291 \pm 25$ & $-20^{* *}$ \\
\hline \multicolumn{4}{|l|}{$\mathrm{GABA}_{\mathrm{B}}$} \\
\hline Granule cell layer & $35 \pm 8$ & $15 \pm 5$ & -57 \\
\hline Molecular layer & $125 \pm 25$ & $52 \pm 22$ & $-58^{* *}$ \\
\hline \multicolumn{4}{|l|}{ Quisqualate } \\
\hline Granule cell layer & $65 \pm 21$ & $31 \pm 4$ & -52 \\
\hline Molecular layer & $109 \pm 16$ & $49 \pm 8$ & $-55^{*}$ \\
\hline \multicolumn{4}{|l|}{ NMDA } \\
\hline Granule cell layer & $53 \pm 13$ & $15 \pm 7$ & $-72^{* *}$ \\
\hline Molecular layer & $16 \pm 5$ & $13 \pm 3$ & -19 \\
\hline \multicolumn{4}{|l|}{$\begin{array}{l}\text { Non-NMDA/Non-QA } \\
\text { binding site }\end{array}$} \\
\hline Granule cell layer & $12 \pm 4$ & $11 \pm 6$ & -8 \\
\hline Molecular layer & $34 \pm 7$ & $9 \pm 3$ & $-74^{* *}$ \\
\hline
\end{tabular}

${ }^{*} P<0.025 ;{ }^{* *} P<0.05$ (Mann-Whitney $U$ test). 

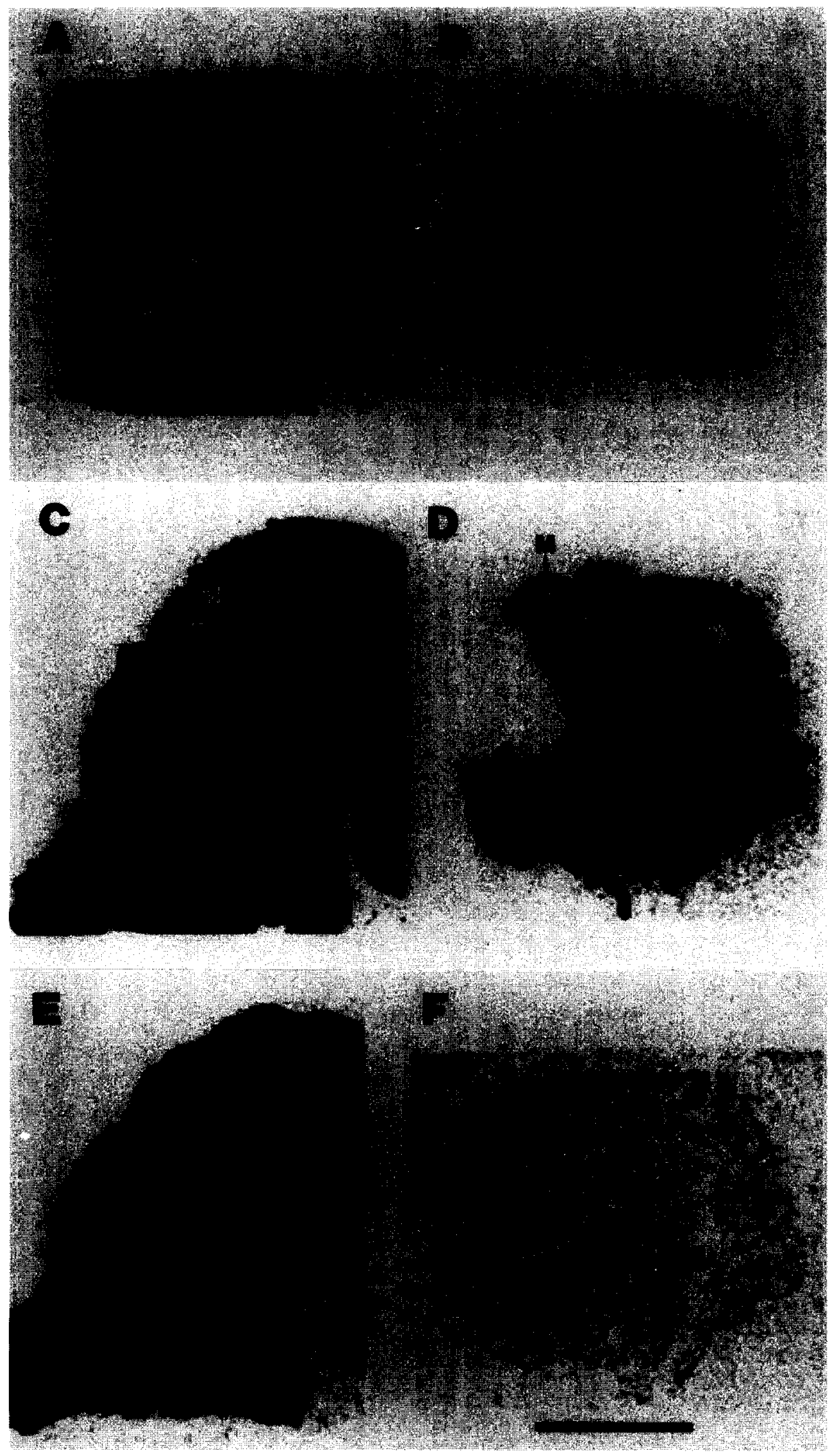

Fig. 1. Autoradiographs of benzodiazepine $(A+B), G A B A_{A}(C+D)$, and $G A B A_{B}(E+F)$ receptors in normal human $(A, C, E)$ and olivopontocerebellar atrophy $(B, D, F)$. The marked atrophy typical of these olivopontocerebellar atrophy specimens is evident in autoradiographs $B, D, F$. BDZ and $G_{A B A}$ receptor density is decreased in OPCA granule cell and molecular layers, GABA $_{B}$ receptor density is decreased in the molecular layer. $M$, molecular layer; $G$, granule cell layer. Scale bar $=5 \mathrm{~mm}$. 

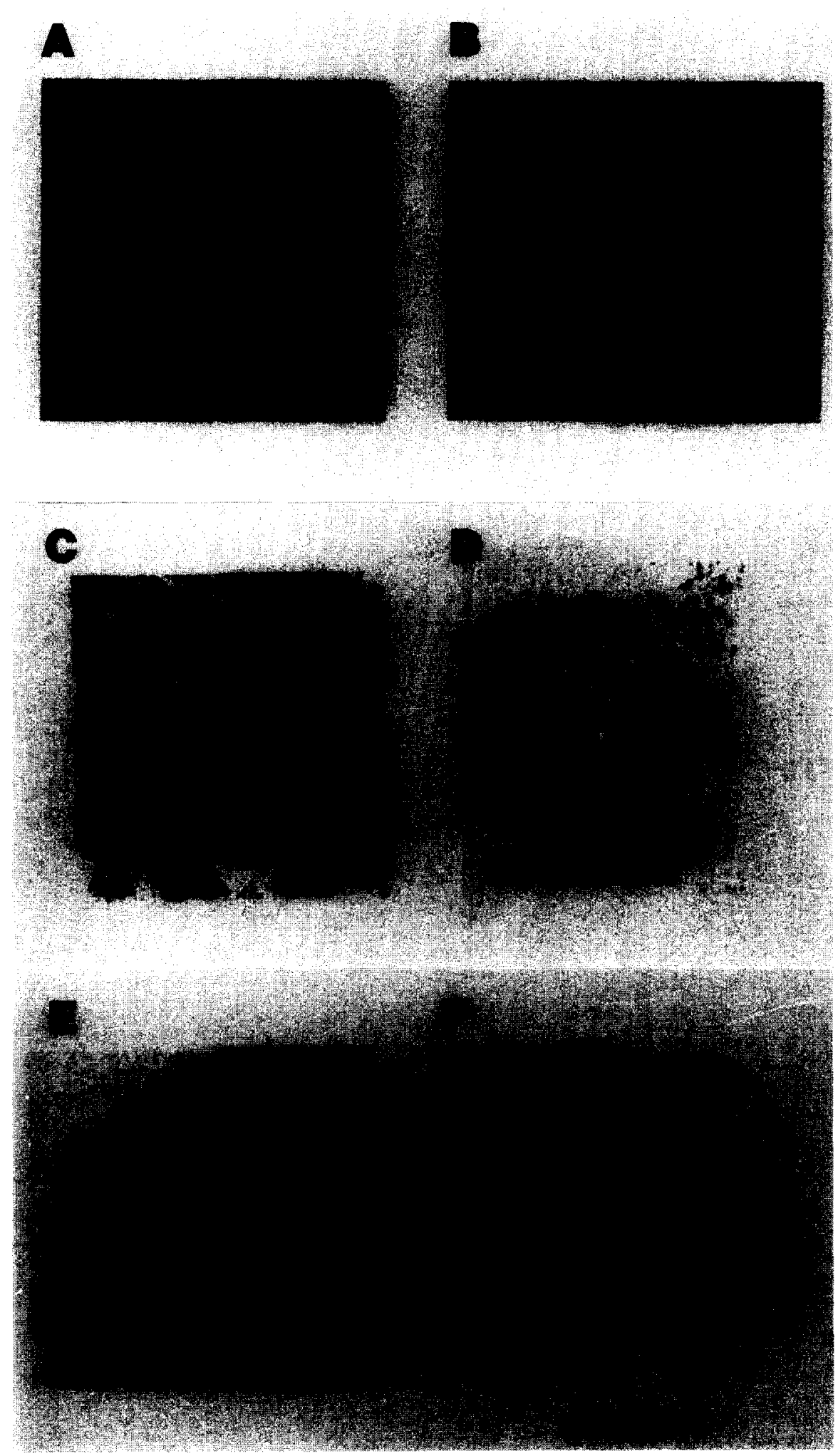

Fig. 2. Autoradiographs of quisqualate receptors $(A+B)$, NMDA receptors $(C+D)$, and non-NMDA/non-QA $(E+F)$ binding in normal human $(A, C, E)$ and olivopontocerebellar atrophy $(B, D, F)$. Quisqualate receptor density and non-NMDA/non-QA binding are reduced in the molecular layer while NMDA receptor density is reduced in the granule cell layer of the OPCA specimens. The quisqualate receptor images are produced by digital subtraction of an image of $\left[{ }^{3} \mathrm{H}\right] \mathrm{GLU}$ binding in the presence of $2.5 \mu \mathrm{M}$ quisqualate from an image of total $\left[{ }^{3} \mathrm{H}\right] \mathrm{GLU}$ binding to produce a visual analogue of the method used to determine quisqualate sensitive binding. $M$, molecular layer; $G$, granule cell layer. Scale bar $=5 \mathrm{~mm}$. 
means of measuring QA and NMDA receptors ${ }^{18,60}$. When $\left[{ }^{3} \mathrm{H}\right]$ GLU binding was performed in $50 \mathrm{mM}$ Tris- $\mathrm{HCl}$ plus $2.5 \mathrm{mM} \mathrm{CaCl}$ we determined also the amount of specific binding left after the inclusion of $2.5 \mu \mathrm{M}$ QA and $100 \mu \mathrm{M}$ NMDA. Non-specific binding for the non-NMDA/non-QA displaceable binding was determined by the inclusion of $1 \mathrm{mM}$ GLU. After a 30-min prewash in buffer, slides were incubated in buffer plus ligand with appropriate blockers for $\mathbf{4 5} \mathrm{min}$. Slides then received 4 quick squirts with buffer, followed by 3 quick squirts with $2.5 \%$ glutaraldehyde in acetone.

\section{Data analysis}

As there were no significant differences in receptor density between the neurologically normal and abnormal control specimens, results from these two groups were pooled for comparison with results from the OPCA specimens. Differences in ligand binding between control and OPCA specimens are assumed to reflect changes in receptor density rather than changes in receptor affinity. This assumption is supported by prior homogenate studies. Kish et al. ${ }^{26}$ found no difference in the $K_{\mathrm{d}}$ of $\mathrm{BDZ}$ receptors between OPCA and control specimens. Tsiotos et al. ${ }^{52}$ compared total $\left[{ }^{3} \mathrm{H}\right]$ GLU binding in OPCA and control cerebellar cortex and found no differences in $K_{d}$ or pharmacologic responses between OPCA and control specimens. The significance of differences in ligand binding between OPCA and control specimens was assessed with the Mann-Whitney $U$ test.

\section{Histology}

Sections adjacent to those used for ARG were fixed over formaldehyde vapor and stained with $0.5 \%$ Cresyl violet. Sections were dehydrated in graded alcohols and xylene and coverslips were affixed with Permount.

\section{RESULTS}

\section{Histology}

All OPCA specimens had almost complete loss of Purkinje cells, marked thinning of molecular layers and diminution of granule cell layers. The morphology of all control specimens appeared normal, including specimens from individuals with neurologic disease not affecting the cerebellum.

\section{$B D Z A R G$}

In control specimens, both molecular and granule cell layers exhibited high densities of BDZ receptors (Table I, Fig. 1). In OPCA specimens, there was a marked reduction in $\mathrm{BDZ}$ receptor density in both granule cell and molecular layers (Table I, Fig. 1).

\section{GABA $A R G$}

The overall density of $\mathrm{GABA}_{\mathrm{A}}$ receptors was significantly higher than $\mathrm{GABA}_{B}$ receptors (Table I, Fig. 1). In control specimens, $\mathrm{GABA}_{\mathrm{A}}$ and $\mathrm{GABA}_{\mathrm{B}}$ receptors were distributed differentially within cerebellar cortex. GA$\mathrm{BA}_{\mathrm{A}}$ receptor density was highest in granule cell layer, while $\mathrm{GABA}_{\mathrm{B}}$ receptor density was highest in molecular layer (Table I, Fig. 1). In OPCA specimens, GABA receptor density was reduced significantly in both molecular and granule cell layers (Table I, Fig. 1). GABA receptor density was reduced significantly in molecular layer and there was a non-significant trend towards reduction in granule cell layer (Table I, Fig. 2).

\section{GLU ARG}

QA and NMDA receptors were distributed differentially in the normal human cerebellar cortex (Table I, Fig. 2). QA receptor density was highest in the molecular layer with NMDA receptor density greatest in the granule cell layer. When $\left[{ }^{3} \mathrm{H}\right] \mathrm{GLU}$ binding was measured in $50 \mathrm{mM}$ Tris- $\mathrm{HCl}$ plus $2.5 \mathrm{mM} \mathrm{CaCl}$ with the addition of $2.5 \mu \mathrm{M}$ QA and $100 \mu \mathrm{M}$ NMDA, there was an additional specific $\left[{ }^{3} \mathrm{H}\right] \mathrm{GLU}$ binding site (Table I, Fig. 2). This non-NMDA/non-QA binding site was present in both molecular and granule cell layers with greatest density in the molecular layer. Significant decreases in all $3\left[{ }^{3} \mathrm{H}\right] \mathrm{GLU}$ binding sites were found in OPCA specimens. QA receptor density was reduced in the molecular layer with a non-significant trend towards reduction in the granule cell layer, NMDA receptor density was diminished in the granule cell layer, and non-QA/ non-NMDA $\left[{ }^{3} \mathrm{H}\right] \mathrm{GLU}$ binding was reduced in the molecular layer (Table I, Fig. 2).

\section{PCP ARG}

There was no specific binding of $\left[{ }^{3} \mathrm{H}\right]$ TCP in cerebellar cortex (data not shown).

\section{DISCUSSION}

Our results indicate that the distribution of inhibitory and excitatory amino acid neurotransmitter receptors in human cerebellar cortex is qualitatively similar to the distributions of receptors described in other mammals ${ }^{7}$, $12,30,35,37-39,62$. The sole exception seems to be $\mathrm{BDZ}$ binding. In our material and previous studies of normal human cerebellar cortex, both granule cell and molecular layers are richly endowed with $\mathrm{BDZ}$ receptors ${ }^{15,55,61}$. In contrast, rat cerebellar cortex is distinguished by a high density of BDZ receptors only in the molecular layer ${ }^{38,61}$. Given the overall similarity in the distribution of receptor sites, it is likely that the cellular localizations of inhibitory and excitatory neurotransmitter receptors are the same as those described in other mammals. This latter inference is buttressed by the results we obtained with OPCA specimens.

Rodents with genetic or toxin induced loss of Purkinje cells or Purkinje cell dendrites exhibit diminished molecular layer density of $\mathrm{BDZ}_{\mathrm{GABA}} \mathrm{GA}_{\mathrm{A}}$, and $\mathrm{QA}$ receptors ${ }^{2}$, $8,11,27,32,35,46,48$. Animals with 3-acetylpyridine induced degeneration of climbing fibers have normal density of $\mathrm{BDZ}$ and $\mathrm{GABA}_{\mathrm{A}}$ receptors ${ }^{8,10,23}$. Similarly, genetic, toxin or viral induced loss of granule cells results in depletion of granule cell layer $\mathrm{GABA}_{\mathbf{A}}$ and NMDA 
receptors ${ }^{11,31,34,42,45}$. These results suggest that in rodent molecular layer, $\mathrm{BDZ}, \mathrm{GABA}_{\mathrm{A}}$, and $\mathrm{QA}$ receptors are located primarily on Purkinje cell dendrites; and that in granule cell layer, $\mathrm{GABA}_{\mathrm{A}}$ and $\mathrm{NMDA}$ receptors are located primarily on granule cells. Our data from OPCA cerebellar cortex yield similar results. Purkinje cells were decreased markedly in all OPCA specimens and granule cells were clearly depleted as well. Consistent with the rodent data, we observed substantial reductions in $\mathrm{BDZ}$, $\mathrm{GABA}_{\mathrm{A}}$, and $\mathrm{QA}$ receptor density in the molecular layer of cerebellar cortex in OPCA. NMDA and $\mathrm{GABA}_{\mathrm{A}}$ receptor density was diminished in the granule cell layer of cerebellar cortex in OPCA. Like rodents, molecular layer $\mathrm{BDZ}, \mathrm{GABA}_{\mathrm{A}}$ and $\mathrm{QA}$ receptors are probably on Purkinje dendrites while granule cell layer $\mathrm{GABA}_{\mathrm{A}}$ and NMDA receptors are located on granule cells in humans. Because OPCA is characterized also by loss of climbing and mossy fibers, we cannot exclude the possibility that some receptors are located on these cerebellar cortical afferents, rather than on intrinsic cerebellar cortical neurons.

For $\mathrm{GABA}_{\mathrm{B}}$ receptors, the picture appears somewhat more complex, with evidence from rodent studies suggesting localization of receptors on Purkinje cell dendrites, climbing fibers, and parallel fibers ${ }^{8,9,23,58}$. Our results in OPCA cerebellar cortex are consistent with all these cellular localizations as our specimens exhibited both Purkinje cell and granule cell loss. Climbing fiber loss also occurs regularly in OPCA.

In OPCA specimens, we found reductions in granule cell layer $\mathrm{BDZ}$ receptor density, and in molecular layer the density of the non-NMDA/non-QA $\left[{ }^{3} \mathrm{H}\right] \mathrm{GLU}$ binding site was reduced. The most parsimonious explanation for these results would be localization of some BDZ receptors to granule cells and localization of the nonNMDA/non-QA site to Purkinje cell dendrites. Again, we cannot exclude the possibility that granule cell layer $\mathrm{BDZ}$ receptors and the non-NMDA/non-QA $\left[{ }^{3} \mathrm{H}\right] \mathrm{GLU}$ binding site are located on afferent terminals. As OPCA results frequently in loss of climbing fibers and mossy fibers in addition to Purkinje cell and granule cell depletion, the granule cell layer BDZ receptors could be located on mossy fiber terminals and the non-NMDA/ non-QA $\left[{ }^{3} \mathrm{H}\right] \mathrm{GLU}$ binding site on climbing fiber and/or parallel fiber terminals.

Our finding of a non-NMDA/non-QA displaceable $\left[{ }^{3} \mathrm{H}\right]$ GLU binding site is not unique. Since these assay conditions inhibit binding to the kainate receptor, it is unlikely that this binding site represents a population of kainate receptors ${ }^{18,20}$. Recent studies in our laboratory have documented the existence of this site in rat ${ }^{20}$. Lesion studies in rats have shown that this site is neuronal, a conclusion supported by our present discovery of de- creased density of this site in cerebellar cortex of OPCA patients. In rat, however, there is little binding to this site in the adult cerebellum ${ }^{20}$.

Our data reveal differences in the distribution of receptors thought to be functionally linked. $B D Z$ receptors are thought to be part of the $\mathrm{GABA}_{\mathrm{A}}$ receptor complex and are found usually in association with GABA $_{A}$ receptors $^{14,55}$. We observed a high density of $B D Z$ receptors but a relatively low density of $G A B A_{A}$ receptors in the molecular layer. A similar pattern has been observed in rodent cerebellar cortex ${ }^{55}$. Similarly, using $\left[{ }^{3} \mathrm{H}\right] \mathrm{TCP}$ we found no specific binding to the PCP receptor in human cerebellar cortex despite the presence of NMDA receptors. This discrepancy has been noted previously in rat cerebellum where a disproportionately low level of $\left[{ }^{3} \mathrm{H}\right] \mathrm{TCP}$ binding has been found despite the presence of a moderate density of NMDA receptors ${ }^{30}$. The PCP receptor appears to exist in high and low affinity forms for binding to TCP, with the low affinity form predominating in the cerebellum ${ }^{53}$. Nonetheless, $\left[{ }^{3} \mathrm{H}\right]$ TCP binding is seen in rat granule cell layer ${ }^{30,53}$. Our control human data suggest that the human cerebellar cortical PCP receptor may have a particularly low affinity for TCP.

Our findings in OPCA specimens are at variance with previous studies of $\mathrm{BDZ}$ and GABA receptors in this syndrome. Kish et al. have reported normal levels of $\mathrm{BDZ}$ receptors and increased levels of $\mathrm{GABA}_{\mathrm{A}}$ receptors in homogenates of cerebellar cortex from OPCA patients ${ }^{25,26}$. Whitehouse et al. used receptor autoradiography to examine 4 cases of OPCA and reported diminished $\left[{ }^{3} \mathrm{H}\right]$ muscimol binding to $\mathrm{GABA}_{\mathrm{A}}$ receptors in the granule cell layer and normal binding of $\left[{ }^{3} \mathrm{H}\right]$ flunitrazepam in both layers ${ }^{56}$. The discrepancies between our results and prior work may be explainable in part on the basis of differences in assay technique, i.e., homogenate binding versus ARG, or by the choice of ligands. $\left[{ }^{3} \mathrm{H}\right]$ Muscimol, for example, binds to a high affinity form of the GABA receptor $^{54}$. $\left[{ }^{3} \mathrm{H}\right]$ GABA may be a less selective ligand in this respect. We have observed $\left[{ }^{3} \mathrm{H}\right] \mathrm{GABA}$ binding in the dentate nucleus (Albin et al., unpublished data), an area where $\left[{ }^{3} \mathrm{H}\right]-$ muscimol does not bind ${ }^{56}$.

Another explanation for the difference between our results and prior work lies in the nature of OPCA material. OPCA is a clinically, genetically, and pathologically variable syndrome and the degree of Purkinje cell and granule cell loss is also variable. All the specimens we studied had marked loss of Purkinje cells and loss of granule cells. Based on the published illustrations, it appears that the specimens studied by Whitehouse et al. had considerably less loss of both cell types. Kish et al. used a large number of specimens with 
a variable degree of cell loss as judged by neurochemical assays $^{25,26}$. Cases with mild to moderate cell loss might not show the changes in receptor density exhibited by our severely affected material, especially as atrophy of the cerebellar folia might elevate receptor density and obscure negative changes in absolute receptor number in specimens with mild to moderate cell loss. Our cases, with their marked Purkinje cell loss and granule cell depletion, are more similar to the various animal models of cerebellar neuron depletion than OPCA cases with mild to moderate loss of Purkinje and granule cells. Kish et al. have also suggested that early OPCA might be marked by upregulation of $\mathrm{GABA}_{\mathrm{A}}$ receptors on the remaining cerebellar neurons ${ }^{25}$. Although there is no direct evidence to support this hypothesis, Troncoso et al. have observed increased density of cerebellar cortical BDZ receptors in the early stages of canine inherited ataxia, a disorder of Gordon setters characterized by gradual degeneration of Purkinje and granule cells $\mathbf{s}^{51}$.

Our results extend the work of Tsiotos et al. ${ }^{52}$, who recently described decreased $\left[{ }^{3} \mathrm{H}\right]$ glutamate binding sites in homogenates from the same OPCA cases studied in the present report. Tsiotos et al. did not measure glutamate receptor subtypes and the use of homogenates precluded regional localization of decreases in receptor subtypes. Nonetheless, the present data, obtained with different assays of GLU receptors, reveal changes of similar magnitude to those reported by Tsiotos et al.

Our finding of decreased density of QA receptors in the molecular layer complements a recent report by Kish et al. of diminished $\left[{ }^{3} \mathrm{H}\right]$ inositol 1,4,5-triphosphate binding in OPCA cerebellar cortical homogenates ${ }^{24}$. In rodent cerebellum, the phosphatidylinositide (PPI) second messenger system is associated with Purkinje cell dendrites $^{5}$. Kish et al. inferred from their OPCA data a similar localization in human cerebellar cortex. The PPI system in rodent cerebellum appears to be driven by activation of a QA receptor ${ }^{5}$. Consequently, our finding of diminished QA receptors in OPCA molecular layer and their probable location on Purkinje cell dendrites supports the inference of Kish et al. that the human cerebellar PPI system is localized in Purkinje cell dendrites.

Our data from OPCA specimens also have implications for efforts to image cellular changes in human neurodegenerative diseases in vivo with positron emis-

\section{REFERENCES}

1 Albin, R.L., Cha, J.J., Makowiec, R.L., Young, A.B., Gilman, S. and Plaitakis, A., Autoradiographic analysis of cerebellar amino acid neurotransmitter receptors in olivopontocerebellar atrophy and Friedreich's ataxia, Neurology, 39 Suppl. 1 (1989) 423. sion tomography (PET). The marked reductions we found in cerebellar cortical neurotransmitter receptors suggest that PET ligands for neurotransmitter receptors may be able to detect cellular changes in OPCA patients in vivo. BDZ receptors, by virtue of their relatively high density and the availability of high affinity ligands that cross the blood brain barrier (BBB), may be good targets for initial studies. In preliminary experiments, we have demonstrated depletion of $\mathrm{BDZ}$ receptors in OPCA with the BDZ ligand Ro15-1788 (Albin et al., unpublished data), a compound already used successfully in humans for PET visualization of $\mathrm{BDZ}$ receptors ${ }^{40}$. Because of their overall high density in cerebellar cortex, $\mathrm{GABA}_{\mathrm{A}}$ and QA receptors may also be good targets if high affinity ligands that cross the BBB can be developed.

In summary, we have studied the distribution of $\mathrm{BDZ}$ receptors, $\mathrm{GABA}_{\mathrm{A}}$ receptors, $\mathrm{GABA}_{\mathrm{B}}$ receptors, $\mathrm{QA}$ receptors, NMDA receptors, PCP receptors, and nonNMDA/non-QA $\left[{ }^{3} \mathrm{H}\right] \mathrm{GLU}$ binding sites in normal human and OPCA cerebellar cortex. BDZ, GABA $A_{A}$, and NMDA receptors have a relatively high density in the granule cell layer while $\mathrm{BDZ}, \mathrm{GABA}_{\mathrm{B}}, \mathrm{QA}$ and the non-NMDA/non-QA $\left[{ }^{3} \mathrm{H}\right] \mathrm{GLU}$ binding sites have a relatively high density in the molecular layer. Our study of OPCA specimens is consistent with the localization of $\mathrm{QA}, \mathrm{GABA}_{\mathrm{A}}$, and $\mathrm{BDZ}$ receptors on Purkinje cell dendrites and NMDA and $G A B A_{A}$ receptors on granule cells in human cerebellar cortex. $\mathrm{GABA}_{\mathrm{B}}$ receptors may be on Purkinje cell dendrites, parallel fiber terminals, or climbing fibers. Our findings are concordant with prior experimental animal data and indicate that the synaptic organization of human cerebellar cortex is largely similar to that of other mammals, although the presence of relatively high densities of $\mathrm{BDZ}$ receptors in the granule cell layer and the non-NMDA/non-QA $\left[{ }^{3} \mathrm{H}\right] \mathrm{GLU}$ binding site in the molecular layer indicate some features different from rodents.

\footnotetext{
Acknowledgements. We thank Zane Hollingsworth and Kevin Kaatz for efficient technical assistance. Kevin O'Mara provided valuable assistance with photography. We are grateful to Dr. Wallace W. Tourtellotte and the staff of the National Neurologic Research Bank for the provision of the Friedreich's ataxia and multiple sclerosis specimen. We are particularly grateful to Dr. Andreas J. Plaitakis for the provision of OPCA specimens and for a critical reading of the manuscript. This work was supported by NIH Grants NS 15655, NS 19613, NS 07222, and NS 01300.
}

2 Angelatou, F., Mitsacos, A., Goulas, V. and Kouvelas, E.D., $\mathrm{L}$-Aspartate and L-glutamate binding sites in developing normal and 'nervous' mutant mouse cerebellum, Int. J. Dev. Neurosci., 5 (1987) 373-381.

3 Beitz, A.J., Larson, A.A., Monaghan, P., Altschuler, R.A., Mullett, M.M. and Madl, J.E., Immunohistochemical localization of glutamate, glutaminase and aspartate aminotransferase in 
neurons of the pontine nuclei of the rat, Neuroscience, 17 (1986) $741-753$

4 Berciano, J., Olivopontocerebellar atrophy: a review of 117 cases, J. Neurol. Sci., 53 (1982) 253-272.

5 Blackstone, C.D., Supattone, S. and Snyder, S.H., Inositolphospholipid-linked glutamate receptors mediate cerebellar parallel-fiber-Purkinje-cell synaptic transmission, Proc. Natl. Acad. Sci. U.S.A., 86 (1989) 4316-4320.

6 Bowery, N.G., Hill, D.R., Hudson, A.L. and Price, G.W., GABA-B receptors. In R.F. Squires (Ed.), GABA and Benzodiazepine Receptors, Vol. 1, CRC Press, Inc., Boca Raton, FL, 1988, pp. 107-121.

7 Bowery, N.G., Hudson, A.L. and Price, G.W., GABA-A and GABA-B receptor site distribution in rat central nervous system, Neuroscience, 20 (1987) 365-383.

8 Bowery, N.G., Price, G.W., Turnbull, M.J. and Wilkin, G.P., Comparison of the cellular locations of GABA-A and GABA-B receptors in the cerebellum using neurologically mutant mice, Br. J. Pharmacol., 79 (1983) 189P.

9 Bowery, N.G., Price, G.W., Turnbull, M.J. and Wilkin, G.P., Evidence for the presence of GABA-B receptors on cerebellar Purkinje cells, Br. J. Pharmacol., 79 (1983) 189P.

10 Braestrup, C. and Squires, R.F., Brain specific benzodiazepine receptors, Br. J. Psychiatry, 133 (1978) 249-260.

11 Chang, R.S.L., Tran, V.T. and Snyder, S.H., Neurotransmitter receptor localizations: brain lesion induced alterations in benzodiazepine, GABA, beta-adrenergic and histamine H1-receptor binding, Brain Research, 190 (1980) 95-110.

12 Chu, D.C.M., Albin, R.L., Young, A.B. and Penney, J.B., Distribution and kinetics of GABA-B binding sites in rat central nervous system: a quantitative autoradiographic study, Neuroscience, 34 (1990) 341-351.

13 Chu, D.C.M., Penney, J.B. and Young, A.B., Cortical GABA$B$ and GABA-A receptors in Alzheimer's disease: a quantitative autoradiographic study, Neurology, 37 (1987) 1454-1459.

14 Enna, S.J., GABA-A receptors. In R.F. Squires (Ed.), GABA and Benzodiazepine Receptors, CRC Press, Boca Raton, FL, 1988, pp. 91-106.

15 Faull, R.L.M., Villiger, J.W. and Holford, N.H.G., Benzodiazepine receptors in the human cerebellar cortex: a quantitative autoradiographic study and pharmacological study demonstrating the predominance of type I receptors, Brain Research, 411 (1987) 379-385.

16 Foster, G.A. and Roberts, P.J., Neurochemical and pharmacological correlates of inferior olive destruction in the rat: attenuation of the events mediated by an endogenous glutamatelike substance, Neuroscience, 8 (1983) 277-284

17 Freeman, M.E., Lane, J.D. and Smith, J.E., Turnover rates of amino acid neurotransmitters in regions of rat cerebellum, $J$. Neurochem., 40 (1983) 1441-1447.

18 Greenamyre, J.T., Olsen, J.M.M., Penney, J.B. and Young, A.B., Autoradiographic characterization of $N$-methyl-D-aspartate-, quisqualate- and kainate-sensitive glutamate binding sites, J. Pharmacol. Exp. Ther., 233 (1985) 254-263.

19 Harding, A.E., The Hereditary Ataxias and Related Disorders, Churchill Livingstone, New York, 1984, 266 pp.

20 Higgins, D.S., Greenamyre, J.T., Young, A.B. and Penney, J.B., A unique glutamate site in an autoradiographic assay, Soc. Neurosci. Abstr., 15 (1989) 1163.

21 Hudson, D.B., Valcana, T., Bean, G. and Timiras, P.S., Glutamic acid: a strong candidate as the neurotransmitter of the cerebellar granule cell, Neurochem. Res., 1 (1976) 73-81.

22 Ito, M., The Cerebellum and Neural Control, Raven Press, New York, 1984, 347 pp.

23 Kato, K. and Fukuda, H., Reduction of GABA receptor binding induced by climbing fiber degeneration in the rat cerebellum, Life Sci., 37 (1985) 279-288.

24 Kish, S.J., Li, P.P., Robaitaille, Y., Currier, R., Gilbert, J., Schut, L. and Warsh, J.J., Cerebellar $\left[{ }^{3} \mathrm{H}\right]$ inositol-1,4,5-triphosphate binding is markedly decreased in human olivopontocere- bellar atrophy, Brain Research, 489 (1989) 373-376.

25 Kish, S.J., Perry, T.L. and Hornykiewicz, O., Increased GABA receptor binding in dominantly-inherited cerebellar ataxias, Brain Research, 269 (1983) 370-373.

26 Kish, S.J., Perry, T.L. and Hornykiewicz, O., Benzodiazepine receptor binding in cerebellar cortex: observations in olivopontocerebellar atrophy, J. Neurochem., 42 (1984) 466-469.

27 Lippa, A.S., Sano, M.C., Coupet, J., Klepner, C.A. and Beer, B., Evidence that benzodiazepine receptors reside on cerebellar Purkinje cells: studies with 'nervous' mutant mice, Life Sci., 23 (1978) 2213-2218.

28 Madsen, S., Ottersen, O.P. and Storm-Mathisen, J., Immunocytochemical visualization of taurine neuronal localization in the rat cerebellum, Neurosci. Lett., 60 (1985) 255-260.

29 Maragos, W.F., Chu, D.C.M., Young, A.B., D'Amato, C.J. and Penney, J.B., Loss of hippocampal $\left.{ }^{3} \mathrm{H}\right] \mathrm{TCP}$ binding in Alzheimer's disease, Neurosci. Lett., 74 (1987) 371-376.

30 Maragos, W.F., Penney, J.B. and Young, A.B., Anatomic correlation of NMDA and ${ }^{3} \mathrm{H}$-TCP-labeled receptors in rat brain, J. Neurosci., 8 (1988) 493-501.

31 Matsokis, N. and Valcana, T., $\left[{ }^{3} \mathrm{H}\right] \mathrm{GABA}$ binding in the cerebellum of the reeler murine mutant, Neurochem. Int., 7 (1985) 37-44

32 Mimaki, T., Deshmukh, P.P. and Yamamura, H.I., Decreased benzodiazepine receptor density in rat cerebellum following neurotoxic doses of phenytoin, J. Neurochem., 35 (1980) 1473-1475.

33 Monaghan, D.T., Bridges, R.J. and Cotman, C.W., The excitatory amino acid receptors: their classes, pharmacology, and distinct properties in the function of the central nervous system, Annu. Rev. Pharmacol. Toxicol., 29 (1989) 365-402.

34 Olsen, R.W. and Mikoshiba, K., Localization of gammaaminobutyric acid receptor in the mammalian cerebellum: high levels in granule layer and depletion in agranular cerebella of mutant mice, $J$. Neurochem., 30 (1978) 1633-1636.

35 Olson, J.M.M., Greenamyre, J.T., Penney, J.B. and Young, A.B., Autoradiographic localization of cerebellar excitatory amino acid binding sites in the mouse, Neuroscience, 22 (1987) 913-923.

36 Ottersen, O.P., Madsen, S., Storm-Mathisen, J., Somogyi, P., Scopsi, L. and Larsson, L.-I., Immunocytochemical evidence suggests that taurine is colocalized with GABA in the Purkinje cell terminals, but that the stellate cell terminals predominantly contain GABA: a light- and electron-microscopic study of the rat cerebellum, Exp. Brain Res., 72 (1988) 407-416.

37 Palacios, J.M. and Kuhar, M.J., Ontogeny of high-affinity GABA and benzodiazepine receptors in the rat cerebellum: an autoradiographic study, Dev. Brain Res., 2 (1982) 531-539.

38 Palacios, J.M., Wamsley, J.K. and Kuhar, M.J., High affinity GABA receptors - autoradiographic localization, Brain Research, 222 (1981) 285-307.

39 Palacios, J.M., Young, W.S. and Kuhar, M.J., Autoradiographic localization of gamma-aminobutyric acid (GABA) receptors in the rat cerebellum, Proc. Natl. Acad. Sci. U.S.A., 77 (1980) 670-674.

40 Pappata, S., Samson, Y., Chavoix, C., Prenant, C., Maziere, M. and Baron, J.C., Regional specific binding of $\left[{ }^{11} \mathrm{C}\right] \mathrm{RO} 151788$ to central type benzodiazepine receptors in human brain: quantitative evaluation by PET, J. Cereb. Blood Flow Metab., 8 (1988) 304-313.

41 Rea, M.A., McBride, W.J. and Rohde, B.H., Regional and synaptosomal levels of amino acid neurotransmitters in the 3-acetylpyridine deafferentated rat cerebellum, J. Neurochem., 34 (1980) 1106-1108

42 Rotter, A., Gorenstein, C. and Frostholm, A., The localization of GABA-A receptors in mice with mutations affecting the structure and connectivity of the cerebellum, Brain Research, 439 (1988) 236-248.

43 Sandoval, M.E. and Cotman, C.W., Evaluation of glutamate as a neurotransmitter of cerebellar parallel fibers, Neuroscience, 3 
(1978) 199-206.

44 Schut, J.W., Hereditary ataxia: clinical study through six generations, Arch. Neurol. Psychiatry, 168 (1950) 75-95.

45 Simantov, R., Oster-Granite, M.L., Herndon, R.M. and Snyder, S.H., Gamma-aminobutyric acid (GABA) receptor binding selectively depleted by viral induced granule cell loss in hamster cerebellum, Brain Research, 105 (1976) 365-371.

46 Skolnick, P., Syapin, P.J., Paugh, B.A. and Paul, S.M., Reduction in benzodiazepine receptors with Purkinje cell degeneration in 'nervous' mutant mice, Nature (Lond.), 277 (1979) 397-399.

47 Somogyi, P., Halasy, K., Storm-Mathisen, J. and Ottersen, O.P., Quantification of immunogold labelling reveals enrichment of glutamate in mossy and parallel fibre terminals in cat cerebellum, Neuroscience, 19 (1986) 1045-1050.

48 Speth, R.C. and Yamamura, H.I., Benzodiazepine receptors: alterations in mutant mouse cerebellum, Eur. J. Pharmacol., 54 (1979) 397-399.

49 Stone, T.W., Glutamate as the neurotransmitter of cerebellar granule cells in the rat: electrophysiological evidence, $B r . J$. Pharmacol., 66 (1979) 291-296.

50 Toggenburger, G., Wiklund, L., Henke, H. and Cuenod, M., Release of endogenous and accumulated exogenous amino acids from slices of normal and climbing fibre deprived rat cerebellar slices, J. Neurochem., 41 (1983) 1606-1613.

51 Troncoso, J.C., Cork, L., Whitehouse, P.J., Kuhar, M.J. and Price, D.L., Canine inherited ataxia: neurotransmitter receptors in the cerebellum, Ann. Neurol., 16 (1984) 135.

52 Tsiotos, P., Plaitakis, A., Mitsacos, A., Voukelatou, G., Michalodimitrakis, M. and Kouvelas, E.D., L-Glutamate binding sites of normal and atrophic human cerebellum, Brain Research, 481 (1989) 87-96.

53 Vignon, J., Privat, A., Chaudieu, I., Thierry, A., Kamenka, J.-M. and Chicheportiche, R., $\left[{ }^{3} \mathrm{H}\right]$ Thienyl-phencyclidine $\left(\left[{ }^{3} \mathrm{H}\right]-\right.$ TCP) binds to two different sites in rat brain. Localization by autoradiographic and biochemical techniques, Brain Research,
378 (1986) 133-141.

54 Walker, F.O., Young, A.B., Penney, J.B., Dorovini-Zis, K. and Shoulson, I., Benzodiazepine receptors in early Huntington's disease, Neurology, 34 (1984) 1237-1240.

55 Wamsley, J.K., McCabe, R.T. and Gehlert, D.R., Autoradiographic localization of binding sites in several GABA and benzodiazepine receptor complexes. In R.F. Squires (Ed.), GABA and Benzodiazepine Receptors, Vol. 1, CRC Press, Inc., Boca Raton, FL, 1988, pp. 79-89.

56 Whitehouse, P.J., Muramoto, O., Troncoso, J.C. and Kanazawa, I., Neurotransmitter receptors in olivopontocerebellar atrophy: an autoradiographic study, Neurology, 36 (1986) 193-197.

57 Wiklund, L., Toggenburger, G. and Cuenod, M., Selective retrograde labelling of the rat olivocerebellar climbing fiber system with $\mathrm{D}-\left[{ }^{3} \mathrm{H}\right]$ aspartate, Neuroscience, 13 (1984) 441-468.

58 Wojcik, W.J. and Neff, N.H., Gamma-aminobutyric acid B receptors are negatively coupled to adenylate cyclase in brain and in the cerebellum these receptors may be associated with granule cells, Mol. Pharmacol., 25 (1983) 24-28.

59 Wuenschell, C.W., Fisher, R.S., Kaufman, D.L. and Tobin, A,J., In situ hybridization to localize mRNA encoding the neurotransmitter synthetic enzyme glutamate decarboxylase in mouse cerebellum, Proc. Natl. Acad. Sci. U.S.A., 83 (1986) 6193-6197.

60 Young, A.B., Greenamyre, J.T., Hollingsworth, Z., Albin, R., D'Amato, C., Shoulson, I. and Penney, J.B., NMDA receptor losses in putamen from patients with Huntington's disease, Science, 241 (1988) 981-983.

61 Young, A.B., Oster-Granite, M.L., Herndon, R.M. and Snyder, S.H., Glutamic acid: selective depletion by viralinduced granule cell loss in hamster cerebellum, Brain Research, 73 (1974) 1-13.

62 Young, W.S. and Kuhar, M.J., Autoradiographic localization of benzodiazepine receptors in the brains of humans and animals, Nature (Lond.), 280 (1979) 393-395. 